\title{
THE ANALYSIS OF THE PROPORTION OF LANGUAGE SKILLS \\ IN ENGLISH TEXTBOOK GRADE XI PUBLISHED BY KEMENDIKBUD 2014
}

\author{
Yuni Wulandari \\ Bengkulu University \\ Yuniwulandari56@yahoo.com \\ Indah Damayanti \\ Bengkulu University \\ indah_078@yahoo.co.id \\ Alamsyah Harahap \\ Bengkulu University \\ Alamsyahharahap18@yahoo.com
}

\begin{abstract}
This study analyzed the proportion of language skills in English textbook using descriptive quantitative method. This study aimed to find out the proportion of language skills in English textbook grade XI published by Kemendikbud 2014, and to find out the suitability of language skills in English textbook grade XI published by Kemendikbud 2014 and the goal of English subject's syllabus for Senior High School. The object of this research was English textbook for grade XI (Senior High School) published by Kemendikbud 2014 (1st and 2 nd semester). The instrument used was evaluation checklist to collect the data about the proportion of language skills. The result showed that the textbook focuses more on writing skills (35\%), grammar (32\%), speaking (25\%), reading (7\%), and listening had the lowest proportion of (1\%). The result of the evaluation showed that this textbook represent the writing skill that integrated with other skills. This textbook has the appropriate proportion on two skills (writing and speaking) however, it has inappropriate proportion on other two skills (listening and reading).
\end{abstract}

Key words: Proportion, Analysis, Language skills, English Textbook

\section{INTRODUCTION}

The main part of teaching and learning process is a good material or activity for students. One of the basic things in teaching material is textbook. According to Brown (2000), "textbooks help teachers to prepare the lesson". Moreover, Setiabudi (2010) state that textbook is course book used by teacher and students to facilitate the teaching learning process that in line with the curriculum suggested. In senior high 
school, especially in English subject an English textbook needed by teacher. English textbookis one of guidance for the teacher to help them in deliver the material to their students. It contains of instruction, material or activity for the students, to improve the students skills in English.

The teacher will know the textbook that they use is appropriate or not based on a deep evaluation. An evaluation of textbook, especially English textbook for grade $\mathrm{XI}$ is also considered to some of educationaljudgment.The proportion of language skills also as consideration to evaluate of an English textbook. Wibisono (2013) state that evaluation will enable teachers to determine whether the language learning plan fit the learners need and interest or not. This judgment will determine the quality of the textbook.

In fact, the four language skills have not implemented proportionally in learning process, namely listening, speaking, reading and writing. There is an assumption in society that reading and writing skill have big proportion rather than the other skills (listening and speaking skill) in English. The assumption is that the proportion of listening and speaking are smaller than reading and writing. The example: in National Exam especially in Senior High School, the students take more time answering their exam on reading the text than answering the question as well as writing skill. The people can see from the content of subject of National Exam (UN), the dominant questions are reading because there are a lot of text such as narrative, descriptive, recount, and procedure text. While, the others skill have less portion.
In this research, the researcher focus on the language skills (listening, speaking, reading and writing). Based on the problem above, the researcher want to gain information of English textbook grade $\mathrm{XI}$ published by Kemendikbud 2014 meet the balance material proportion or notbased on the goal of English subject's syllabus for senior high school

\section{METHOD}

This study is using descriptive quantitative method in evaluating the English textbook, which is focused on the proportion of language skills through the activities inEnglish textbook grade XI published byKemendikbud 2014.

The object of this research is English textbook for grade XI (senior high school) published by Kemendikbud 2014 (1st and 2nd semester). The total of chapter in those two books are eleven chapters.

In this study, the researcher uses an evaluation checklist as the instrument of data collection. The Evaluation checklist is a list of activity and skills that the researcher is going to look at when observing the English textbook. This list have been prepared by the researcher based on chapters and activities in English Textbook grade XI published by Kemendikbud 2014.

The instrument will be conducted by the researcher and co-researcher. The co-researcher will be an English teacher (Mrs. Amelia Eka Frimasary, S.Pd) at SMA N 2 Kota Bengkulu that already used the English textbook grade XI published by Kemendikbud 2014. To determine what activity belong to a certain skill, some criteria by Nation 
(2007) and Nation \& Macalister (2010) is used.

Furthermore, the co-researcher checked the overall results and confirmed what the researcher has done in each chapter on each evaluation checklist, and the purpose of this step is to make the result of this study to be more objective.

The technique of data analysis will using percentage formula. In this data analysis, the result will be in quantitative data in the form of processing numbers. The steps in collecting the quantitative data are as follows.

1. The researcher will developed the checklist based on the activities in the textbook.

2. The data will be analyzed a thorough examination. In conducting the analysis, the textbook was conducted through evaluation checklist. The researcher determines the kinds of English skills presented in each activity. Every activity may represent more than one skills. The examination started from general impression to specific impression based on the criteria in the checklist.

3. The researcher calculated the total of each skill from the activities in every chapter and their percentages. Scores were then given for every skill in every chapter (Each of checklist mark $(v)$ in the language skills and grammar column will be scored one (1) for each and zero (0) for none), and then come to a final score for every skill from all chapters.
The data will be analyzed based on the evaluation checklist, the data formulated in simple statistical percentage :

$$
\mathbf{P}=\frac{f}{n} \mathbf{X} 100 \%
$$

$\mathrm{P}=$ Percentage

$f=$ The number of total score of every skills

$n=$ The number of total score of

all

skills

(Adapted from Sudijono, 2010).

\section{RESULTS AND DISCUSSION}

The result of this study is about the proportion of language skillsin english textbook grade XI published byKemendikbud 2014 shows that writing skill has been given the highest proportion, as showed in figure 1 .

Figure 1. The Proportion of Language skills and Grammar

- Writing $35 \%$ Speaking $25 \%$

neading 7\% घistening 1\%

- Grammar 32\%

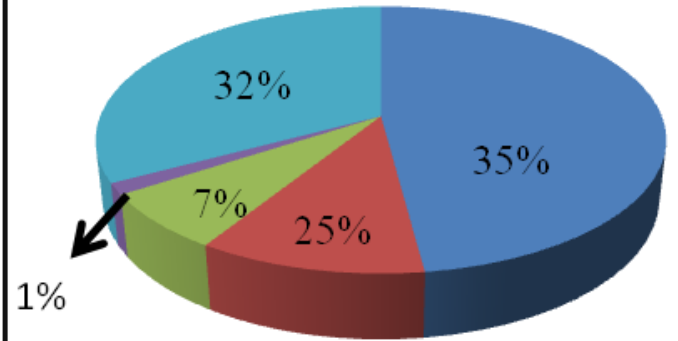

From the figure 1, we can see that writing skill has the highest proportion 
(35\%), grammar (32\%), speaking (25\%), reading $(7 \%)$, and the lowest proportion is listening of (1\%). Big proportion of activities in the textbook was represented by the writing skill that integrated with other skills. Writing skill can be combined to listening, reading and writing skills. Grammar activity in this research can be combined with the other language skills such as: listening, speaking, reading and writing. For example, after the student read the reading activity, the students should make their opinion and understanding about it, in the discussion questions and discussions note. Each chapter in this English textbook shows almost no different proportion for each skills. The detail of the proportion of language skill in each chapter is shown in following Table 1. Percentage (\%) of Language Skills and Grammar for whole chapters.

\begin{tabular}{|c|c|c|c|c|c|}
\hline Chapter & Listening & Speaking & Reading & Writing & Grammar \\
\hline 1 & 0 & 34 & 7 & 34 & 25 \\
\hline 2 & 0 & 33 & 4 & 30 & 33 \\
\hline 3 & 0 & 35 & 5 & 30 & 30 \\
\hline 4 & 0 & 25 & 5 & 35 & 35 \\
\hline 5 & 0 & 25 & 5 & 35 & 35 \\
\hline 6 & 0 & 24 & 5 & 38 & 33 \\
\hline 7 & 0 & 18 & 6 & 41 & 35 \\
\hline 8 & 0 & 14 & 9 & 32 & 45 \\
\hline 9 & 0 & 17 & 6 & 44 & 33 \\
\hline 10 & 6 & 23 & 23 & 32 & 16 \\
\hline 11 & 0 & 26 & 5 & 37 & 32 \\
\hline
\end{tabular}

In chapter 1 speaking and writing skills has the same proportion of $34 \%$, then followed by grammar $25 \%$, reading $7 \%$, and listening $0 \%$.Most of the activities require students to work on writing and speaking than reading skill and grammar. For example in activities such as "personal connection", "discussion questions\&discussion notes", "personal journal writing", "complete the transactions based on suggest and offer given", "active conversation", "write the folklore that has some suggestion and offers on it and share it with your classmates and teacher", "choose one of activities for your project", and "write an Indonesian folklore in English and share it with your teacher and classmates".

Those several activities shows that writing activity integrated with other skills, reading, speaking and grammar. From the proportion of chapter 1 , it shows that this chapter more focus on speaking and writing skills.

Chapter 2 shows the same of proportion of speaking skill and grammar of $33 \%$. In this chapter the speaking skill and grammar are the highest proportion than the others. Writing 30\%, reading $4 \%$, and listening skill $0 \%$ or can we said that there is no listening activity in this chapter. In this chapter students also required to focus more on speaking skill and grammar.

Chapter 3 shows the same proportion of writing and grammar activity of $30 \%$. Meanwhile, writing skill as the highest proportion of $35 \%$. In this chapter focus more on writing skill and reading was the third proportion of only $5 \%$ and listening skill $0 \%$ or can we said again that there is no listening activity in this chapter.

Chapter 4 shows the same proportion of writing and grammar activity of $35 \%$. The others skills percentage of this book are speaking $25 \%$, reading $5 \%$, and listening skill $0 \%$ or can we said again that there is no listening activity in this chapter.

Chapter 5 shows the same result of chapter 4 . The result was $35 \%$ writing, $35 \%$ grammar, $25 \%$ speaking, $5 \%$ reading 
and $0 \%$ listening. There is no different result in this chapter, but the different just on the activities that students do. For example: in chapter 4 students learn about "formal invitation" meanwhile in chapter 5 students learn about "personal letter".

Chapter 6, the activity that mostly appear in this textbook was writing activity. Writing skill considered as the extremely important for students to understanding the questions and material that they learnt. From previous chapters until chapter 6 , the highest proportion of language skills still grasped of writing skill. It was evidenced by the percentage from the evaluation checklist that has been done by researcher and co-researcher. Writing 38\%, grammar33\%, speaking $24 \%$, reading $5 \%$, and $0 \%$ for listening skill.

Chapter 7 shows no significant different among the proportion of language skills and grammar activity. In this chapter the writing skill as the highest portion and grammar are the second highest proportion than the other skills. Writing 41\%, grammar 35\%, speaking $18 \%$, reading $6 \%$, and listening skill $0 \%$ or can we said again that there is no listening activity in this chapter.

Chapter 8 shows that grammar as the highest proportion of $45 \%$ above writing skill. Writing skill decreased in to $32 \%$. Next,the speaking skill of $14 \%$, reading increase to $9 \%$ and listening skill as the same of previous chapters, only for $0 \%$.

Chapter 9 shows that writing skill as the highest proportion of $44 \%$ above the grammar and other language skills. In this chapter focus more on writing skill, followed by grammar of $33 \%$, speaking $17 \%$, and reading was the fourth proportion of only $6 \%$ and listening skill $0 \%$ or can we said again that there is no listening activity in this chapter.

Chapter 10 shows that there are some proportion of listening skill because of this chapter about "Meaning Through Music". This chapter presented some of songs and poem and mixed all the language skills, the proportion of writing still as the highest portion of $32 \%$, reading and speaking was $23 \%$ and $6 \%$ of listening.

Chapter 11 or the last chapter of the English textbook grade XI published by Kemendikbud 2014 still shows that writing skill as the highest proportion of $37 \%$, followed by grammar 32\%, speaking $26 \%$, reading $5 \%$, and listening $0 \%$.

\section{Discussions}

After presenting the results of proportion of language skills and grammar, in this section the results and findings will be discussed by researchers.In Indonesia, especially in Bengkulu province, some schools apply 2013 curriculum. Therefore, the researcher analyze the English textbook grade XI published by kemendikbud 2014 because in line with the implementation of the latest curriculum.

The assumption that listening and speaking are smaller than reading and writing is proven by National Examination especially for Senior High School examine students more on reading the text and answering the question. People can see from the content of subject of National Examination (UN), the dominant questions are reading because there are a lot of text such as narrative, 
descriptive, recount, and procedure text, while the others skill have less portion. In fact, in this research speaking skill was the second dominant skill represented in this textbook. It means speaking has already presented appropriately.

In reality, students of Senior High School are not able to use English for communication in a proper condition. There are many students regard it is very difficult to speak English. This condition could be influenced by the fact that English is considered as a foreign language instead of second language.

\section{The goal of English subject's syllabus in Senior High School}

The Ministry of Education and Culture (2016) state that teaching language at senior high school level focuses on improving the competence of learners to beable to use English to achievecommunication goals in various contexts, both oral and written. The ministry of education and culture (2016) states that in English subject's syllabus in senior high school (SMA / MA / SMK / MAK), the goal of English subject are to develop students' potentials to have communicative competence in interpersonal texts, transactional, and functional, using various texts in English for oral and written. Through the use of such texts, learners are guided to use factual knowledge, conceptual and procedural, and embed the noble values of national character, in the context of life, in the home environment, school, and society. It means that speaking and writing skills have the big proportion than other skills.

The finding of this research shows that writing skill has the highest proportion on English textbook grade XI published by kemendikbud 2014. It is followed by grammar, speaking, reading and writing. The focus in this research is the proportion of language skill. Even though listening skill is the lowest proportion in this textbook, the textbook has many activities with integrated skills. For example: in activity chapter 1, "personal connection" the instruction of this activity was: If you get three wishes from a magical creature, what will you wish for? Write down your wishes in the space given below and share with your teacher and classmates. In this activity, the researcher and co-researcher determine what activity belong to a certain skill based on guidance from Nation (2007) and Nation \& Macalister (2010), in details see on appendix 2 . This activity belongs to the writing skills and speaking skills.

Chapter 8 about "The Last Leaf". In this chapter there is a short story titled "The Last Leaf", based on this material the teacher not only bound to the material in this book only, but the teacher can combine some skills for their student. The teacher can use this short story as a basic material after that they required the students to read it (as reading skill), and listen while their friends or teacher read it (as listening skill), after that the students are require to write down what they have learnt after reading the material for example questions in "discussion questions" activity. Then the teacher ask the student to express their idea or thought in front of the class for speaking activity.

Furthermore, activity in chapter 10, "discussion questions for Hero" (a song by Mariah Carey) the instruction of this activities were: 1 . What is the song 
"Hero" about?, 2. According to the song "Hero", what makes a hero?, 3. Who is your Hero? Why?, 4. How does this song make you feel?. In this activity the student are require the student to work on listening skill and writing skill. Then, still in activity chapter 10 , "choose one song that made you angry or you think it is unrealistic. Change the lyric of the song. Then share it with your class, you can sing a song." In this activity the students are required to work on reading, speaking, and writing skills.

According to Cohen and Riel (1989) writing as a communicative act, a way of sharing information, observation, thoughts or ideas with ourselves and others. It means that writing is an important skill in order to communicate. In line with result that writing skill as the highest proportion students focus more on writing and speaking skills, because those skills are important for students as the center, and make the students confidence, active, and productive. Moreover, speaking is one of language skill which is very important to be mastered by students in order to be a good communicator. Speaking is the verbal use of language to communicative with others. It is important to make students learn these skills more than the other skills because these skills known as productive skills. Speaking and writing belong to the productive skills, because the learner produce an output.

From the result of the research, writing skill as the highest proportion and followed by speaking skill make the students improve their ability to communicate with other people in oral and written form and minimize the mistake when students want to express their thought with write it first. This result of proportion shows that this textbook made based on the standard from the government and 2013 curriculum in order to make students more active, creative, and as a center as the goal of 2013 curriculum.

Chrystal (2015) states that listening is the first skill that should be acquired by student in learning a language. It means that from the four language skills are interrelated and the students should acquired listening first, without listening no communication can be achieved because by listening the student can continue to speaking, reading, and writing. It will be better if listening skill should have more portion in this textbook or the proportion of language skills this English textbook should near of balance proportion than those like in this textbook because listening is one of the important skills.

\section{The Linkage between the Result and Previous Studies}

There are some previous studies that related to the researcher's research. First, Wibisono (2013) entitled "Proportion Of Language Skills In English Textbook English On Sky 1"has the similarity with the researcher such as the aim of Wibisono's research is to analyze the proportion of language skills in the textbook. Writing and speaking skill as the highest proportion than the other skills. The instrument was developed by the researcher. The result of the research both the researchers were focus more on writing and speaking skill in the language skills proportion, it proved by the percentage of each research such as in the researcher research the proportion was $35 \%$ of 
writing, 32\% of speaking and Wibisono's research the proportion was $29 \%$ of writing, and $26 \%$ of speaking.

The differences such as the level of students, in Wibisono's research he used English Textbook English On Sky 1 published by Erlangga (grade VII for Junior high school) andfocus on 2006 curriculum, meanwhile in this research, the researcher used English textbook published by Kemendikbud 2014 (grade XI for senior high school) and 2013 curriculum.

Second, Setiabudi (2010) entitled "The Analysis of English Textbook "English On Sky 2". The focuses of this study are the language skills and communicative exercises, meanwhile the researcher focus only on language skills. The object of this studyand the curriculum used are the same with Wibisono (2013) that is an English textbook for the second year of Junior High School, and using 2006 curriculum or school-based curriculum.In collecting the data, he used document as data source.

Third, Lathif (2015) entitled "An Evaluation of English Textbooks for the Eighth Graders of Junior High School". The differences such as the level of students, in Lathif's research he used English Textbook for the eight graderof Junior high school.While, the researcher focus on grade XI textbook for senior high school. The focus of this study was analyzing documents which were two English textbooks in a systematic and replicable manner.

The aim of this descriptivequalitative study was to understand and to gain the depiction of worthiness of English textbooks as shown by their strength and weakness.
Whereas the researcher using descriptive quantitative study and aimed to find out the proportion of language skills in English textbook grade XI published by Kemendikbud 2014. In Lathif's research the data were gathered by evaluating textbooks using the checklist containing thecriteria of textbook evaluation. In the researcher's research used evaluation checklist and guidance theory (four strands) by Nation (2007) and Nation \& Macalister (2010).

The results of Lathif's research showed that Let's Talk and English on Sky 2 are appropriate to be used in teaching learning process based on the criteria synthesized from the ones determined Pusat Perbukuan and other ELT experts. And the result of this research showed that this textbook is appropriate for grade XI students in senior high school which implemented 2013 curriculum because the author made the textbook based on government standard that applying the 2013 curriculum to reach the goals of 2013 curriculum are to prepare the next generation of Indonesia to become self-confidence, productive, creative,innovative, affective, and able to contribute to the society, nation, state, and world civilization.

\section{CONCLUSION AND SUGGESTION}

Based on the results of this research, it can be concluded that: writing skill has the highest proportion of 35\%, grammar $32 \%$, speaking $25 \%$, reading $7 \%$, and the lowest proportion is listening of $1 \%$. Most of activities in the textbook represent writing skill that integrated with other skills. In this textbook, there are many skills that are integrated each 
other. This textbook has the appropriate proportion on two skills (writing and speaking) however, it has inappropriate proportion on other two skills (listening and reading).

\section{Suggestion}

According to the results of this study, the researcher sums up some suggestions forsides that arerelated to theresults.

First, this research might help the English teachers to combine some skills for activities in the textbook. The teachers should add material from other sources, internet or other books that still relate to the material in the textbook in order to help the students increase their knowledge especially for listening skill.

Second, for English textbook's writer. In this textbook, the proportion shows that writing skill as the highest proportion, followed by speaking, reading, and the lowest proportion was listening skill. It will be better if the English Textbook's writer from Kemendikbud or all Englishtextbook's writer balanced on language skills proportion in each activities. Such as they could add more activities on listening and reading skills in order to make the proportion on all language skills are not too far and to cover the lack of listening and reading activity.

Third, this research might help the next researchers who want to conduct a similar research about the proportion of language skills in English textbook. The next researchers can also conduct research that not only focus on the proportion of language skills but also on other field such as the suitability of the English subject syllabus goal to this textbook.

\section{REFERENCES}

Brown, H.D. (2000). Principles Of Language Learning And Teaching (4th Edition).NewYork : Addison Wesley Longman.

Cohen, M. and Margareth. R. (1989). The Effect of Distances of Students' Writing. American Education Research Journal. 26,(2), pp.143159.

Crystal, D. (2015). Ensiklopedi Bahasa. The Cambridge Encyclopedia of Language. Bandung: Nuansa Cendikia.

Kementerian Pendidikan dan Kebudayaan. (2014). Bahasa Inggris for Grade XI Senior High School. Jakarta: Kementerian Pendidikan dan Kebudayaan.

Kementerian Pendidikan dan Kebudayaan. (2016). Silabus Mata Pelajaran

Sekolah Menengah Atas/Madrasah Aliyah/Sekolah Menengah Kejuruan/ Madrasah Aliyah Kejuruan (Sma/Ma/Smk/Mak).Jakarta:Kemen terian Pendidikan dan Kebudayaan.

Lathif, M. (2015). An Evaluation of English Textbooks For The Eight Graders

Junior High School. Thesis. English language education program, faculty of language an arts. Yogyakarta State University. 
Nation, P. (2007). The Four

Strands.Innovation in Language

Learning and Teaching. 1(1), 1-12.

Nation, I.,\& Macalister, J.

(2010).Language Curriculum

Design. New York: Routledge.

Setiabudi, I. (2010). The Analysis of English Textbook "English on

Sky

2" Used at the Second Year of SMP Dharma Karya,

Pamulang.

Skripsi, English Education

Department, Faculty of

Tarbiyah

Syarif

and Teachers' Training, UIN

Hidayatullah Jakarta.

Wibisono, A. (2013). Proportion of

Language Skills in English

Textbook English onSky 1.

Sarjana's Thesis. University of

Malang. 